\title{
Sustainable Development: Bonding Inertia of a Resource Based Economic Specialization
}

\author{
Irina Roshchina ${ }^{1, *}$, Ekaterina Lisovskaya ${ }^{2}$, Igor Krishtal ${ }^{2}$, and Olga Levshina ${ }^{2}$ \\ ${ }^{1}$ Tomsk State University, Institute of Economics and management, 634050 Lenin Avenue, 36, Tomsk, \\ Russia \\ ${ }^{2}$ Plekhanov Russian University of Economics, 117997Stremyanny lane 36, Moscow, Russia
}

\begin{abstract}
This article is focused on the issues of interdependence between resources and economic development. The inability to form universal approaches to ensuring sustainable development is caused by constant change of public development conditions and substantial differences between territories. The objective of this research is to reveal distinctive tendencies in the performance of Russia's economic system in view of exploring possibilities of achieving sustainable development in regions with a large number of monotowns. The hypothesis of the research is a thesis that sustainable development of the Russian economy at all levels is affected by the growth holding inertia caused by its resource based specialization. It was confirmed that among factors affecting sustainable development of the Russian economy are its specialization in natural resources, fragmented material production, lack of a national science-based engineering core and a non-developed internal market, priority support by the government of large private companies both in industry and finance and reliance on foreign investments. The analysis of sustainable development of Kemerovo Oblast confirmed the first part of the conclusions made by Thanh Le and Cuong Le Van - the use of nonrenewable resources limits economic growth. It is currently impossible to verify the second part of their conclusions as applied to Kemerovo Oblast. The main condition - rational economic structure - is out of the picture. The process of sustainable development is affected by dominating resource based industrial specialization and as a result by high dependence of socio-economic development and regional budgets on world commodity prices.
\end{abstract}

\section{Introduction}

During the last two decades much attention has been paid to the issues of sustainable development. Despite of that an ideal view of the mechanisms allowing to ensure sustainable development have not been formed. The inability to work out a universal approach comes as a result of a broad variety of settings in which each economy functions as a complex socio-economic system. Various approaches are formed taking into account

\footnotetext{
*Corresponding author:riv58@yandex.ru
} 
more components of socio-economic development, providing a broader view of various economic, social and ecological indicators. For example, in 2012 The UN Sustainable Development Solutions Network (UN SDSN) has been set up to mobilize global scientific and technological expertise to promote practical solutions for sustainable development. Along with indicators frequently used to evaluate the physical aspect of social capital, new ones have been introduced to take into account the sense of security and confidence about the future, the level of trust and generosity.

The issue of ensuring sustainable development is especially pressing for monotowns. [1; 2]. On single-industry territories in Russia small business is underdeveloped. In monotowns about $25 \%$ of employees including individual entrepreneurs are employed in small or medium enterprises. In the EU countries, US and Japan small and medium enterprises account for more than $50 \%$ of total employment. [3].

In Russia the number of monotowns exceeds 300. Among the top 5 regions ranked by the number of monotowns are Kemerovo Oblast (24 monotowns), Sverdlovsk Oblast (17 monotowns), Chelyabinsk Oblast (15 monotowns), the Republic of Karelia (11 monotowns), Irkutsk Oblast (8 monotowns). On the average about 9\% of Russia's population are monotown dwellers, while in 10 Russian federal subjects more than $20 \%$ of people live in monotowns. Kemerovo Oblast ranks first having $60,2 \%$ of monotown population.

According to the National ecological rating of Russia's regions published in 2018 by the Russian public organization "Green Patrol", among its 85 federal subjects the aforementioned regions are ranked as follows:

- Kemerovo Oblast - No. 38;

- Sverdlovsk Oblast - No. 85;

- Chelyabinsk Oblast - No. 84;

- the Republic of Karelia - No. 37;

- Irkutsk Oblast - No. 83.

In Kemerovo Oblast the majority of pollution emissions $-60,7 \%$ - comes from the extraction of mineral resources, which is a city-forming enterprise for most monotowns of the region. The decrease in population here is higher than in any other region of the Siberian Federal District, which is a clear trend. According to the local office of the Russian Federal State Statistics Service average negative migration balance in Kemerovo Oblast is 10 thousand people a year. Natural population decline holds approximately the same share in total population decline. In 2018 death rate exceeded birth rate in Kemerovo Oblast by $44 \%$.

The structure of employment in the region is indicative of resource-based industrial development. One third of monotowns in Kemerovo Oblast are in the "red zone", which means that socio-economic situation in these monotowns is disturbing. Among them are coal-mining towns (Prokopyevsk, Anjero-Sudjensk and others) and a number of towns specializing in ferrous metallurgy and mining equipment manufacture.

The objective of this research, its main results being briefly outlined in this article, is to reveal distinctive tendencies in the performance of Russia's economic system at different levels in view of exploring possibilities of achieving sustainable development.

The hypothesis of the research is a thesis that sustainable development of the Russian economy at all levels is affected by the growth holding inertia of its resource based specialization under a non-rational economic structure.

\section{Materials and Methods}

In accordance with the objective we will analyze the profile of sustainable development of the Russian economy and tendencies that are being formed. Then we will examine the way 
these tendencies affect sustainable development of regional economies with a singleindustry structure.

The issue of interdependence between economic growth and natural resources has been in the center of attention of numerous researches for quite some time. Nevertheless, a single view has not been formed. This issue is being analyzed from different angles:

1. Bringing out a group of key factors, affecting economic growth. Some researchers believe, that natural resources were essential for economic development up to the XX century, others believe it lasted up to the middle of the XX century. Nowadays capital and labour rather than natural resources are dominating factors of economic growth. [4].

2. Studying the relation between natural resources and income and the way they affect the development of national economies. For example, Gobind T. Nankani (1979); Jeffrey D. Sachs and Andrew M. Warner $(1997,2001)$ believe that the abundance of natural resources negatively affects economic development of countries with low and medium income levels [5-7].

3. Analyzing the impact of renewable and non-renewable natural resources on economic growth. For example, according to Thanh Le and Cuong Le Van, the use of non-renewable resources limits economic growth. However if the economy has a rational structure, large reserves of non-renewable resources can positively affect economic growth. «Despite a possible triggering of a negative growth rate, non-renewable resources are able to induce a higher growth rate under some conditions involving the intrinsic growth of renewable resources and the productivity of research activities» [8, p. 224].

4. Studying sustainable development and a "resource curse" (or "Dutch Disease"). The example of flourishing economies with both limited (Hong-Kong, Singapore and Switzerland) and substantial mineral reserves (United States, Canada, Australia, Chile) cast doubt on the theory that "resource curse" (or "Dutch Disease") is caused by the abundance of natural resources. Institutional and demographic factors are brought forward as being most important for economic development. [9].

All of it necessitates taking into account more distinctive features of each economy when analyzing the nature and tendencies of its sustainable development.

One can observe "anti-sustainable" tendencies being formed as it comes to the Russian economy. They manifest themselves in the development of human, physical, nature and institutional capital.

Direct correlation between national currency (ruble), dollar revenues on international commodity markets and global market exchange rates for the US dollar poses a threat for the stability of the whole monetary and credit system and causes inflation on the internal market for goods. Continuous depreciation of the ruble from 1995 to 2019 resulted in a 14 times drop of its value against the dollar. During nearly the same period (1998-2019) the Chinese national currency (yuan) rose by $23.3 \%$ against the dollar (from 8,3 yuan per dollar to 6,7 yuan per dollar in 2019).

Since 2004 Global Competitiveness Index (GCI) is used to generally assess competitiveness of countries with different development statuses. It covers 113 indicators grouped into 12 pillars of economic competitiveness. In the Global Competitiveness Report Russia is ranked 43 among 141 countries [10], which is why its economy is hardly an equal player in the world economy of today.

Russia's economy is an international recipient of knowledge-intensive industrial and consumer goods, technology and foreign investments, primarily into resource-based and food industries, retail and finance. To profoundly evaluate sustainable development processes Global Innovation Index, comprising 82 different parameters, can also be used. This index allows to take into account both resources available and innovation environment (Innovation Input) and practical innovation results (Innovation Output) [11]. According to Global Innovation Index Russia is ranked 46 among 129 countries with an overall score of 
37,9 out of 100 . It means that in terms of innovation performance the first 10 national economies score almost twice as good as Russia's economy (from 1,8 to 1,5 times). The roots for Russia's economy to be far from innovative despite certain local growth of innovative potential lie in a faulty strategy of 1990's to ingrate into the world economy following the principle "oil in exchange for manufactured goods" and in an "open door" economic policy. Rapid development of resource-based industries resulted, mainly oil and gas, resulted in almost total collapse of the national market for medium and highly knowledge-intensive products. As a consequence a substantial basis for global competitiveness has been undermined, which entailed: 1) fading commodity demand and the loss of sources for domestic investment; 2) priority support by the financial system of emerging large private companies in oil and gas and private bank sector; 3 ) the loss of professional skills by workers and specialists.

The attempts to attract large-scale foreign investments that have been made could not break the vicious circle "domestic investment market - national knowledge-based engineering" given low international competitiveness of most Russian knowledge-based engineering companies. The share of machinery and equipment does not exceed $7 \%$ in Russia's total export of goods, while their share in import is more than 50\%. Large-scale attraction of foreign investments will cause ultimate liquidation of national knowledgebased engineering and further strengthening of "anti-sustainable" tendencies in economic development.

One of the key factors undermining Russia's economic stability is its resource based specialization in international trade that is still in place (Russia's key exports are hydrocarbons, wood, minerals, etc.). Russia holds the 3-d place in the world in terms of energy coal supply.

A few steady negative trends have manifested themselves as to the performance of the Russian economy. They include:

- the lack in technology in most production industries;

- high resource intensity in material production;

- the lack of a national base for technology intensive engineering;

- high levels of monopolization in industry, trade and finance;

- constant shortage of investment in all sectors;

- increasing role of foreign capital in finance, industry and trade;

- the loss of highly qualified specialists and scientists due to cross-border migration.

Having a highly resource based economy, Kuzbass is one the most developed regions both in the Siberian Federal District and in the Russian Federation. The extraction of a nonrenewable resource - coal - dominates, contributing around $32,8 \%$ of gross regional product.

Despite negative dynamics in gross regional product from 2012 to 2017 (except for 2014 and 2017), manufacturing in comparable prices rose by $18 \%$ due to the increase in output of coal, coke and oil products, chemicals and chemical products, machinery and equipment.

In view of this the attempts and best practices of different countries, where mining represents an important economic sector (Canada, Australia, South Africa, Chile, and Peru) [12] in achieving sustainable development are of interest. For instance, China's experience in maintaining coordinated economic growth, environment and resources in coal-based regions may be of relevance. If Kuzbass is a typical mining region in Russia, Shanxi province is typical coal-based province in China [13].

Human Development Index of Kemerovo Oblast is 0.848 (it rates 53 among all Russian regions). Professional mobility of available workers in monotowns is low. Specific features and problems of social and employment relations in monotowns of Kemerovo Oblast have 
been analyzed by the example of Leninsk-Kuznetsky monotown and its systemic company Suek-Kuzbass JSC. [14].

In 2019 Kemerovo Oblast dropped from 34 to 49 in The National Investment Climate Rating, which caused an outflow of business to other regions.

Russia's Agency for Strategic Initiatives (ASI) evaluated investment climate in all of the 34 Kuzbass municipalities. Rated in Top-10: Novokuznetsk, Kemerovo, Mezhdurechensk, Osinniki, Prokopyevsk District, Berezovsky, Anjero-Sudjensk, Belovo, Krapivninsk and Promyshlenovsk districts.

XXIV annual Investment Attractiveness Evaluation made by RAEX Rating Agency shows that "resource" regions do not always demonstrate positive development dynamics. Kemerovo Oblast has lost 7 ranking positions and now rates 62-nd.

It is possible to evaluate economic stability rather accurately using the Life Quality Index. In RIA's rating of Russian regions in terms of quality of life Kemerovo Oblast ranks 54-th (with a total score of 43,260 ) out of 85 possible ranking positions. Tomsk Oblast that shares borders with Kemerovo Oblast, is ranked 51-st (with a total score of 44,469). They are not only neighboring regions, but are ranked very close, being in the middle of the rating list. Meanwhile Kemerovo Oblast has a mostly resource-based specialization, while Tomsk Oblast is positioned as an innovative region.

\section{Results and Discussion}

The assessment of the level of sustainable development of a monotown should be based on the following criteria that were identified in the course of the analysis of the correlationbetween different approaches to the study of models of sustainable system development:

- the preservation and augmentation of human potential;

- growth in the living standard;

- an increase in the social responsibility of the city-forming enterprise and the development of the social partnership system;

- financial and economic stability of the city-forming enterprise;

- diversification of specialization and employment patterns;

- favorable environmental situation.

All indicators assessing the sustainable development of a monotown should be divided into three groups:

1. Indicators assessing social sustainability.

2. Indicators assessing economic sustainability.

3. Indicators assessing environmental sustainability.

Since we consider the city-forming enterprise and the monotown as a single system, both their indicators are used when assessing sustainable development. A more detailed system for monitoring the processes of sustainable development of a monotown is described in a number of publications [15 - 18].

The fact that regions with different economy specialization have similar living standards ratings allows us to form a hypothesis for further. As a hypothesis, one can put forward a substantiation of the thesis that the recognized trio of factors (economic, social, environmental), which play a decisive role in ensuring sustainable economic development, must be supplemented by an institutional factor.

The COVID-19 pandemicthat actedas a catalyst for economic crisis greatly increases the relevance of efficient measures for monotowns support.

There is a variety of practices for ensuring sustainable development of certain territories in the Russian Federation. Priority Social and Economic Development Area system, in particular (PSEDA). Positive results of this particular practice in the Far East region make it 
possible to recommend expansion of the PSEDA program to include monotowns. This will enable timely response to the escalation of existing and emergence of the new problems that significantly complicate the functioning of these territories in the context of a new crisis.

To increase the level of diversification of the single-industry economy structure and the gradual formation of a rational structure of the economy, it is necessary to create favorable conditions for the use of all types of economic activity of PSEDA in monotowns. To this end, mechanisms for concessional lending to small and medium-sized enterprises should be created. Granting a status of PSEDA resident may be considered as a tool for stimulating entrepreneurial activity.

\section{Conclusion}

The results of this study confirm that the process of sustainable development of the Russian economy is restrained by the inertia ofirrational structure of its natural resources specialization. Predominance of the raw materials sector in the production specialization of the regional economy and, as a result, the high level of dependence of socio-economic development and the possibilities of the regional budget in the Kemerovo region on the situation on commodity markets is a particular example of such an effect.

The analysis of the processes of sustainable development of the Kemerovo region also confirms the first part of the conclusions of Thanh Le andCuong Le Van which states that the use of non-renewable resources limits economic growth. As for the second part of their conclusions, at the current moment they are impossible to verify as the key condition rational structure of the economy - is missing.

The process of formation of an economy of sustainable development in Russia is being slowed down by the following factors: international natural resource specialization, fragmentation of the sphere of material production, lack of a national core of high-tech engineering, a developed domestic national market, priority state support of large private business in industry and finance, and orientation towards foreign investment.

The development of small and medium-sized businesses in Russian production is significantly lagging. The manufacturing sector of the Russian economy is fragmented, does not represent a single national complex, and is under the ever-increasing influence of foreign capital, which is not interested in its innovative development.

\section{References}

1. E. Satybaldina, Journal of Advanced Research in Law and Economics. Craiova 6(2), 376-377 (2015)

2. K. Storey, H. Hall, Canadian Geographer, 62(2), 225-237 (2018)

3. Entrepreneurship at a Glance 2015 (OECD Publishing, Paris, 2015)

4. K. Zaman, A. Abdullah, A. Khan, Renew. Sustain. Energy Rev., 56, 1263-1271 (2016)

5. Development Problems of Mineral-exporting Countries. (The World Bank, Washington, 1979)

6. J. Sachs, J. Warner, Afr. Econ., 6(3), 335-376 (1997).

7. J. Sachs, J. Warner, Eur. Econ. Rev., 45, 827-838 (2001)

8. L. Thanh, L. Cuong, Journal Economic Modelling, 70, 215-229 (2018)

9. S. Ruchir, Wall Street Journal, 2, 6 (2015)

10. The Global Competitiveness Report 2019 (WEF, Genoa, 2019) 
11. The Global Innovation Index 2019 (Cornell University, Ithaca, 2019)

12. Trends in the mining and metals industry: mining's contribution to sustainable development (International Council on Mining \&Metals, Ottawa, 2012)

13. L. Li, Journal Resources Policy, 55, 80-86 (2018)

14. I. Roshina, N. Artyukhova. WELLSO 2016 Future Academy, 43-50 (2017)

15. I. Roshina, N. Artyukhova. RPTSS 2015, 28, 1-4 (2016)

16. I. Roshina, N. Artyukhova. ITSMSSM 2016, Atlantis Press, 435-438 (2016)

17. I. Roshina, N. Artyukhova. RRI 2016 Future Academy, 823-829 (2017)

18. N. Artukhova, I. Roshchina, G. Kalyanova, M. Katz. E3S Web Conf., 41, 04008 (2018) 